\title{
Artificial induction and isolation of cadmium-tolerant soil bacteria
}

\author{
Sangman Lee ${ }^{1}$
}

Received: 9 January 2020 / Accepted: 21 March 2020 / Published Online: 30 June 2020

(C) The Korean Society for Applied Biological Chemistry 2020

\begin{abstract}
Environmental pollution caused by various heavy metals is a serious global problem. To solve this problem, microbial bioremediation of contaminated metals has developed rapidly as an effective strategy when physical and chemical techniques are not suitable. In this study, cadmium (Cd)-tolerant soil bacteria were isolated via artificial induction in laboratory conditions instead of screening bacteria naturally adapted to metal-contaminated soils. Wild-type (WT) bacteria grown in uncontaminated soils were artificially and sequentially adapted to gradually increasing $\mathrm{Cd}$ concentrations of up to $15 \mathrm{mM}$. The resultant cells, named Soil-CdR15, survived at a Cd concentration of $10 \mathrm{mM}$, whereas WT cells failed to survive with $4 \mathrm{mM} \mathrm{Cd}$ on solid media for $2 \mathrm{~d}$. In liquid media containing $\mathrm{Cd}$, the SoilCdR15 cells grew with $15 \mathrm{mM} \mathrm{Cd}$ for $7 \mathrm{~d}$, whereas the WT cells could not grow with $5 \mathrm{mM} \mathrm{Cd}$. Both Soil-CdR15 and WT cells removed approximately $35 \%$ of $\mathrm{Cd}$ at the same capacity from liquid media containing either 0.5 or $1.0 \mathrm{mM} \mathrm{Cd}$ over $2 \mathrm{~d}$. In addition to $\mathrm{Cd}$, the Soil-CdR15 cells showed increased resistance to nickel, zinc, and arsenic compared to WT cells. The Soil-CdR cells were identified as Burkholderia sp. by partial sequencing of $16 \mathrm{~S}$ rRNA. The data presented in this study demonstrate that isolation of heavy metal-tolerant microorganisms via artificial induction in laboratory conditions is possible and may be useful for the application of the microorganisms for the bioremediation of heavy metals.
\end{abstract}

Keywords Bioremediation - Cadmium - Environment Heavy metal $\cdot$ Soil bacteria

Sangman Lee $(\bowtie)$

E-mail: sangman@knu.ac.kr

${ }^{1}$ Division of Applied Biology and Chemistry, School of Applied Biosciences, College of Agriculture and Life Sciences, Kyungpook National University, Daegu 702-701, Republic of Korea

This is an Open Access article distributed under the terms of the Creative Commons Attribution Non-Commercial License (http://creativecommons. org/licenses/by-nc/3.0/) which permits unrestricted non-commercial use, distribution, and reproduction in any medium, provided the original work is properly cited.

\section{Introduction}

Heavy metals have become one of the most prevalent and concerning environmental pollutants worldwide [1]. Non-essential heavy metals, including cadmium $(\mathrm{Cd})$, lead, mercury, and chromium, are not needed for the growth of organisms and can be toxic at low concentration. They are non-degradable and, therefore, must be separated from living organisms. The typical methods for cleaning up toxic heavy metals from contaminated soils and waters involve physical and chemical methods [2]. These methods are effective when the contaminated area is small and the concentration of metals is high. However, they are expensive, can make the land infertile because of the removal of all essential elements during the clean-up procedure, and ineffective for large areas contaminated with low metal concentrations. Therefore, as an alternative to the typical methods, bioremediation, which uses microorganisms to clean up pollutants from a contaminated site, has been developed [3-7].

There has been rapid progress in techniques for microbial bioremediation of heavy metals [8-10]. Biosorption, as a bioremediation of metal removal in wastewaters, using either live or dead microorganisms has been suggested as effective and economic technique when the contaminated metal concentrations are not high [11]. Bioremediation of $\mathrm{Cd}$ was conducted by metal -resistant mutated bacteria isolated from industrial effluent [12]. Saccharomyces cerevisiae was used for removing $\mathrm{Cd}$ from aqueous waste solutions [9]. Therefore, one of recent research focus is improving the development of organisms that possess both, a higher tolerance to heavy metals and the ability to accumulate them in large amounts. In general, bacteria that are pre-exposed to heavy metals for a long time have a greater tolerance than those that are not pre-exposed because of the adaptation of the bacteria to metal stress [13]. The adaptation includes both physiological and genetic changes. Most of heavy metal-tolerant microorganisms have been isolated from areas polluted with heavy metals, and these organisms have reduced various metal contents in metal-polluted wastewaters $[10,14-$ 18]. 
Cadmium-resistant mutants of Aspergillus nidulans were isolated by exposing to ultraviolet [19]. Copper-tolerant mutants of sake yeast were isolated by treatment of ethyl methanesulfonate [20]. And, the development of metal tolerance in soil communities was conducted in agricultural soils amended with different heavy metals in laboratory conditions [21]. However, there has been a lack of studies on whether heavy metal-tolerant microorganisms can be generated artificially by exposing them to heavy metal stress in laboratory conditions.

Most heavy metals, including $\mathrm{Cd}$, have mutagenic effects [22, 23]. Thus, the long-exposure of microorganisms to heavy metals in artificial conditions can induce metal tolerance by inducing mutations during the adaptation process. Therefore, this study focused on the artificial generation of bacterial mutants that have a strong tolerance to $\mathrm{Cd}$, a representative non-essential heavy metal, using the sequential adaptation of bacteria to gradually increases in Cd stress.

\section{Materials and Methods}

\section{Induction and isolation of Cd-resistant bacteria}

A soil sample was collected from a rose garden at Kyungpook National University, Korea. Approximately $5 \mathrm{~g}$ soil was mixed with $10 \mathrm{~mL}$ Luria-Bertani (LB) medium, and $100 \mu \mathrm{L}$ of the supernatant was inoculated in $5 \mathrm{~mL} \mathrm{LB}$ medium. The cells were incubated for $24 \mathrm{~h}$ at $30^{\circ} \mathrm{C}$ with shaking at $200 \mathrm{rpm}$. Then, $100 \mu \mathrm{L}$ of the grown cells was inoculated in $5 \mathrm{~mL} \mathrm{LB}$ medium containing $100 \mu \mathrm{M} \mathrm{CdCl}_{2}$ and incubated until cell growth reached a level close to saturation. If the cells grew well within $48 \mathrm{~h}$, then the experiment was repeated by inoculating $100 \mu \mathrm{L}$ of the grown cells in new media in which the $\mathrm{Cd}$ concentration was gradually increased in $100 \mu \mathrm{M}$ units up to $1000 \mu \mathrm{M}$. After this point, the $\mathrm{Cd}$ concentrations were gradually increased in $1 \mathrm{mM}$ units. If the inoculated cells did not grow well in the medium with the higher concentration of $\mathrm{Cd}$ within $48 \mathrm{~h}$, the cells grown in the previous $\mathrm{Cd}$ concentration were inoculated in medium with a $\mathrm{Cd}$ concentration that was either the same or lower than the previous concentration of Cd. The Cd-resistant soil bacteria (named Soil$\mathrm{CdR} 15$ ) were isolated by growing cells in media containing $\mathrm{Cd}$ and gradually increasing the concentration of $\mathrm{CdCl}_{2}$ to $15 \mathrm{mM}$, and this procedure took approximately 3 months.

\section{Identification of Soil-CdR15 based on 16S rRNA}

The genomic DNA of Soil-CdR15 cells was extracted using a MagListo $^{\text {TM }}$ 5M Genomic DNA Extraction Kit (Bioneer, Daejeon, Korea), and the $16 \mathrm{~S}$ rDNA was amplified via polymerase chain reaction (PCR). The universal primers 27F (5'-AGA GTT TGA TCC TGG CTC AG-3') and 1492R (5'-GGC TAC CTT GTT ACG ACT T-3') were used. The PCR reaction conditions were as follows: an initial denaturation at $95^{\circ} \mathrm{C}$ for $5 \mathrm{~min}$; 30 cycles of denaturation at $95{ }^{\circ} \mathrm{C}$ for $30 \mathrm{~s}$, primer annealing at $56^{\circ} \mathrm{C}$ for $30 \mathrm{~s}$, and extension at $72{ }^{\circ} \mathrm{C}$ for $90 \mathrm{~s}$; a final extension at $72{ }^{\circ} \mathrm{C}$ for 10 min; and cooling of the amplified products to $4{ }^{\circ} \mathrm{C}$. The amplified PCR products were analyzed by $0.8 \%(\mathrm{w} / \mathrm{v})$ agarose gel electrophoresis and purified using a Gel Extraction Kit (Invitrogen, Carlsbad, CA, USA). The purified DNA fragments were sent to Solgent (Daejeon, Korea) for sequencing.

\section{Assay for metal sensitivity}

First, $50 \mu \mathrm{L}$ of wild-type (WT) or Soil-CdR15 cells was inoculated in $5 \mathrm{~mL}$ LB media containing various concentrations of metals $\left(\mathrm{CdCl}_{2}, \mathrm{NiCl}_{2}, \mathrm{ZnCl}_{2}\right.$, and $\mathrm{Na}_{2} \mathrm{HAsO}_{4}$ obtained from SigmaAldrich, St. Louis, MO, USA) and incubated for $24 \mathrm{~h}$, or another indicated time, at $30{ }^{\circ} \mathrm{C}$ with shaking at $200 \mathrm{rpm}$. Cell densities were then measured using spectrophotometry at $600 \mathrm{~nm}$. WT and Soil-CdR15 cells $(10 \mu \mathrm{L})$ were grown for $48 \mathrm{~h}$ at $30{ }^{\circ} \mathrm{C}$ on $\mathrm{LB}$ agar media containing the indicated $\mathrm{Cd}$ concentrations and then imaged.

\section{Analysis of Cd removal}

After preparation of $15 \mathrm{~mL}$ LB medium in a flask containing either 0.5 or $1.0 \mathrm{mM} \mathrm{CdCl}_{2}, 5 \mathrm{~mL}$ of the medium was each aliquoted into two flasks. Then, $100 \mu \mathrm{L}$ of WT or Soil-CdR cells was inoculated in the media and incubated for $3 \mathrm{~d}$ at $30{ }^{\circ} \mathrm{C}$ with shaking at $200 \mathrm{rpm}$. These cells were spun down by centrifuging at $16,800 \times \mathrm{g}$ for $10 \mathrm{~min}$, and this was repeated three times to remove the cells. Total $\mathrm{Cd}$ concentrations of the media were determined using inductively coupled plasma atomic emission spectrometry (ICP-AES; Optima 7300DV, PerkimElmer, Waltham, MA, USA) via serial dilution of sample. Multi-element standard solution V (Merck Chemicals, Darmstadt, Germany) was used as reference standard. The ICP-AES was calibrated for $\mathrm{Cd}$ by running different concentrations of standard solutions $(0.1,1$, and $10 \mathrm{mg} / \mathrm{L})$.

\section{Statistical analysis}

Data (Figs. 3, 4) are presented as the mean \pm standard deviation (SD) of three independent experiments. A one-way analysis of variance (ANOVA) was carried out to measure significant differences among the groups at the significant level of $5 \%$, $p<0.05$ using a SPSS program with a 23.0 version.

\section{Results and Discussion}

\section{Cd-tolerance analysis of Soil-CdR15 bacteria}

The isolated Cd-resistant Soil-CdR15 cells showed a higher tolerance to Cd than WT cells (Fig. 1). The growth of WT cells was inhibited significantly on solid media containing $2 \mathrm{mM} \mathrm{Cd}$, and only a few WT colonies appeared when the Cd concentration was $3 \mathrm{mM}$, which was possibly due to the survival of a few types of soil bacteria that had an inherent tolerance to that $\mathrm{Cd}$ concentration. When the Cd concentration was higher than $5 \mathrm{mM}$, 


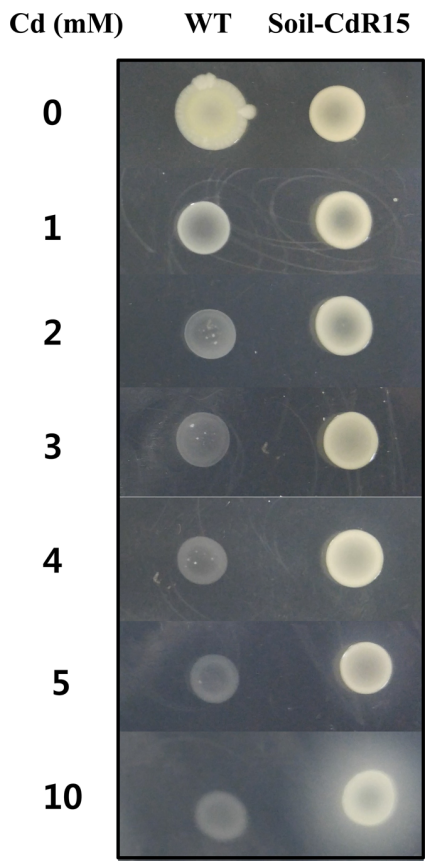

Fig. $1 \mathrm{Cd}$ sensitivities of WT and soil-CdR15 cells. WT and soil-CdR15 cells were grown for $48 \mathrm{~h}$ at $30{ }^{\circ} \mathrm{C}$ on agar media containing the indicated $\mathrm{Cd}$ concentrations, and images were then taken. WT, wild-type soil bacteria; soil-CdR15, soil bacteria adapted to $15 \mathrm{mM} \mathrm{Cd}$ stress

the WT cells could not survive. In contrast, the Soil-CdR15 cells showed no significant growth retardation until the $\mathrm{Cd}$ concentration reached $5 \mathrm{mM}$ and survived even with $10 \mathrm{mM} \mathrm{Cd}$. Cd-tolerance analysis in liquid media also showed a higher tolerance of SoilCdR15 cells compared with WT cells (Fig. 2). The growth of WT cells was almost inhibited with $5 \mathrm{mM} \mathrm{Cd}$, whereas the Soli-CdR cells were inhibited with $12.5 \mathrm{mM} \mathrm{Cd}$ for $1 \mathrm{~d}$. After a $3 \mathrm{~d}$ incubation time, WT cells showed no growth with $5 \mathrm{mM} \mathrm{Cd}$, whereas the Soil-CdR cells grew with $15 \mathrm{mM} \mathrm{Cd}$. After a $7 \mathrm{~d}$ incubation time, WT cells did not grow with $5 \mathrm{mM} \mathrm{Cd}$, whereas the Soil-CdR15 cells survived with $15 \mathrm{mM} \mathrm{Cd}$.

\section{Analysis of Cd removal from media}

The Cd removal capacity of WT and Soil-CdR15 cells was compared by growing both cells in liquid media containing either $0.5 \mathrm{mM}$ or $1.0 \mathrm{mM} \mathrm{Cd}$ for $3 \mathrm{~d}$ (Fig. 3). There was no significant difference in $\mathrm{Cd}$ removal capacity, and both cell types removed approximately $35 \%$ of the Cd present in the liquid media after $3 \mathrm{~d}$. Even though the Soil-CdR15 cells did not exhibit a higher $\mathrm{Cd}$ removal capacity compared to WT cells, they can be used for $\mathrm{Cd}$ removal at $\mathrm{Cd}$ concentrations at which WT cells cannot survive. Moreover, it is difficult to obtain yeast species that are both hyperaccumulative and tolerant to heavy metals [24]. Therefore, this study focused on acquiring heavy metal-tolerant microorganisms which may be useful for application in bioremediation of highly $\mathrm{Cd}$ contaminated waste waters.
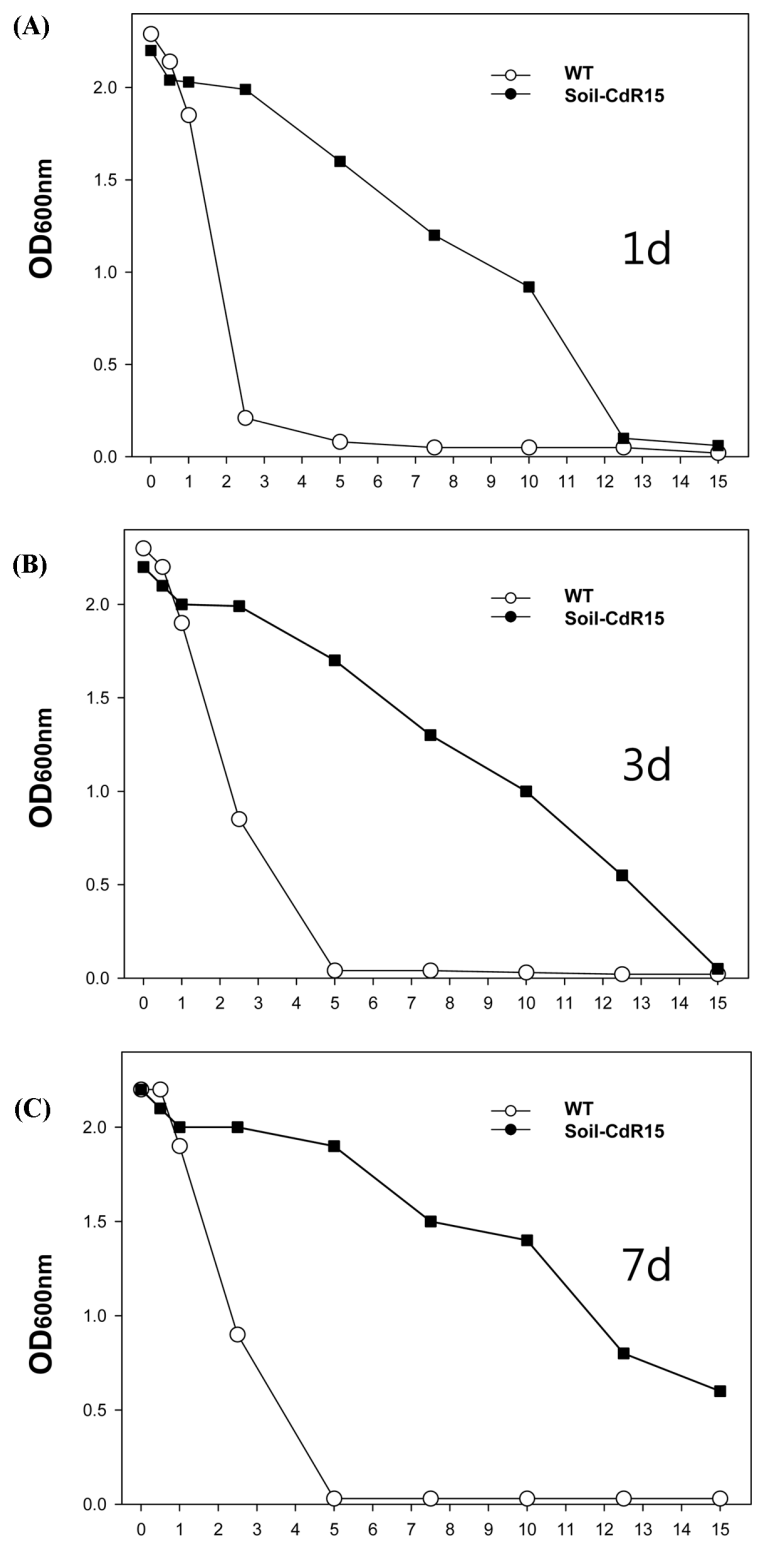

$\mathrm{Cd}(\mathrm{mM})$

Fig. 2 Survival analysis of WT and soil-CdR15 cells over time to high levels of Cd. WT and soil-CdR15 cells were grown in liquid media containing various concentrations of $\mathrm{Cd}$ for the indicated time at $30^{\circ} \mathrm{C}$. Cell densities were then measured at $600 \mathrm{~nm}$ after $1 \mathrm{~d}$ (top), $3 \mathrm{~d}$ (middle), and $7 \mathrm{~d}$ (bottom) using a spectrophotometer. WT, wild-type soil bacteria; soil-CdR15, soil bacteria adapted to $15 \mathrm{mM} \mathrm{Cd}$ stress

\section{Tolerance analysis of Soil-CdR15 to $\mathrm{Ni}$, As, and Zn}

Occasionally, microorganisms that have adapted to one type of metal stress acquire tolerance to other metals $[18,25]$. Soil bacterial communities became tolerant to metals other than the metals added to soils [14]. Hence, the sensitivity of the Soil-CdR15 cells to other metals was analyzed. Compared to WT cells, the SoilCdR15 cells showed an increased tolerance to Ni (Fig. 4A), Zn 


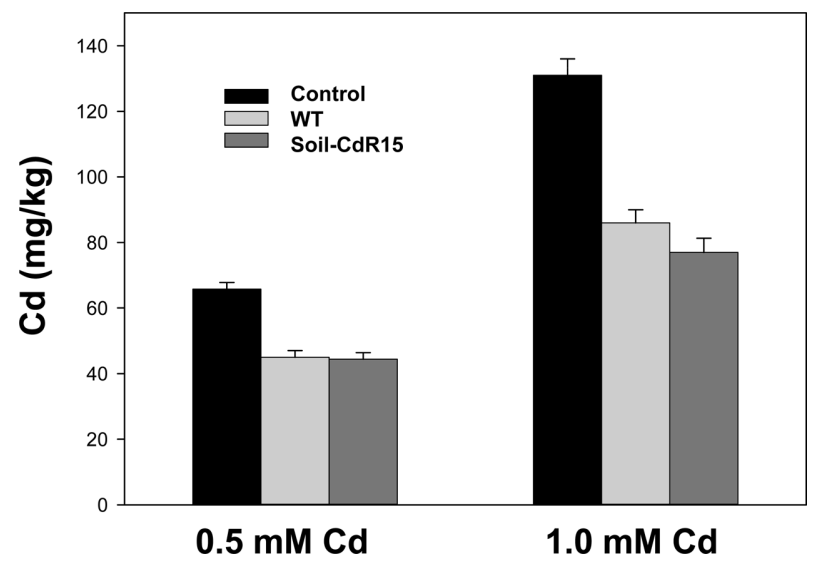

Fig. 3 Cd-removal analysis of WT and soil-CdR15 cells. WT and soilCdR15 cells were grown in liquid media containing either (A) 0.5 or (B) $1.0 \mathrm{mM} \mathrm{Cd}$ for $3 \mathrm{~d}$ at $30^{\circ} \mathrm{C}$. Then, the $\mathrm{Cd}$ concentrations in the media were measured. Values shown are the mean $\pm \mathrm{SD}$ (standard deviation) of three replicates. Control, medium without inoculation; WT, wild-type soil bacteria; soil-CdR15, soil bacteria adapted to $15 \mathrm{mM} \mathrm{Cd}$ stress

(Fig. 4B), and As (Fig. 4C). The Soil-CdR15 cells showed $20 \%$ and WT cells showed $\sim 90 \%$ inhibition of growth in liquid media containing $2 \mathrm{mM}$ Ni. For Zn stress, WT cells showed $\sim 85 \%$ inhibition of growth at $10 \mathrm{mM} \mathrm{Zn}$, whereas the Soil-CdR15 cells did not show significant inhibition of growth until $30 \mathrm{mM} \mathrm{Zn}$. For As stress, the Soil-CdR15 cells showed $\sim 10 \%$ and WT cells showed $\sim 55 \%$ inhibition of growth at $30 \mathrm{mM}$ As.

\section{Identification of Soil-CdR15 by sequencing of 16S rRNA}

The Soil-CdR 15 cells may be either a single cell type or mixture of several types of cells. To identify the cells, 10 single colonies were prepared by streaking them on solid media. Then, metal tolerance was analyzed by growing them in liquid media as described in Fig. 2 and Fig. 4. The analysis indicated that all colonies looked similar (data not shown). Then, 16S rRNA from all the 10 colonies was sequenced. All sequencing results indicated that the Soil-CdR15 cells are Burkholderia sp.

In conclusion, the results of this study suggest that heavy metaltolerant microorganisms can be artificially developed in laboratory conditions by adapting naturally grown microorganisms to higher concentrations of metal stress. The results presented here will be useful for the development of an effective method for the bioremediation of heavy metals using microorganisms.

\section{References}

1. Ali H, Khan E, Sajad MA (2013) Phytoremediation of heavy metalsconcepts and applications. Chemosphere 91: 869-881

2. Wuana RA, Okieimen FE (2011) Heavy metals in contaminated soils: a review of sources, chemistry, risks and best available strategies for remediation. ISRN Ecology 2011: 1-20

3. Bai HJ, Zhang ZM, Yang GE, Li BZ (2008) Bioremediation of cadmium
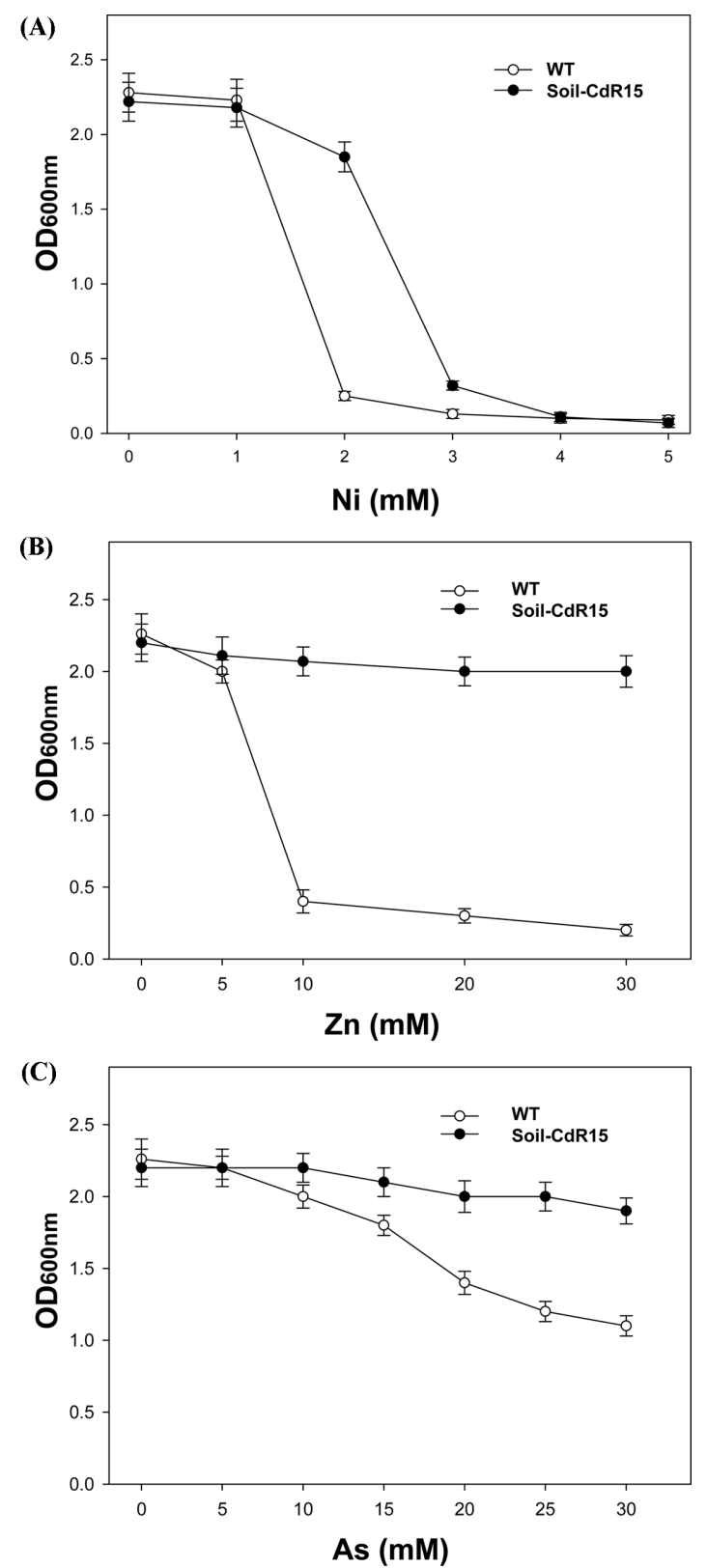

Fig. 4 Sensitivity of WT and soil-CdR15 cells to Ni, Zn, and As. WT and soil-CdR15 cells were grown in liquid media containing various concentrations of (A) Ni, (B) $\mathrm{Zn}$, and (C) As for $24 \mathrm{~h}$ at $30^{\circ} \mathrm{C}$. Cell densities were then measured at $600 \mathrm{~nm}$ using a spectrophotometer. Values shown are the mean $\pm \mathrm{SD}$ (standard deviation) of three replicates. WT, wild-type soil bacteria; soil-CdR15, soil bacteria adapted to $15 \mathrm{mM}$ Cd stress

by growing Rhodobacter sphaeroides: Kinetic characteristic and mechanism studies. Bioresource Technol 99: 7716-7722

4. Gad AS, Attia M, Ahmed HA (2010) Heavy metals bio-remediation by immobilized Saccharomyces cerevisiae and Opuntia ficus indica waste. J American Sci 6: 79-87

5. Soares EV, Soares HM (2012) Bioremediation of industrial effluents containing heavy metals using brewing cells of Saccharomyces cerevisiae as a green technology: a review. Environ Sci Pollut Res Int 19: 1066-1083 
6. Gaur N, Flora G, Yadav M, Tiwari A (2014) A review with recent advancements on bioremediation-based abolition of heavy metals. Environ Sci Processes Impacts 16: 180-193

7. Srivastava J, Naraian R, Kalra SJS, Chandra H (2014) Advance in microbial bioremediation and the factors influencing the process. Inl $\mathrm{J}$ Environ Sci Tech 11: 1787-1800

8. Tsekova K, Todorova D, Ganeva S (2010) Removal of heavy metals from industrial wastewater by free and immobilized cells of Aspergillus niger. International Biodeterioration \& Biodegradation 64: 447-451

9. El-Sayed MT (2012) The use of Saccharomyces cerevisiae for removing cadmium(II) from aqueous waste solutions. African J Microbiol Res 6: 6900-6910

10. Khan Z, Hussain SZ, Rehman A, Zulfiqar S, Shakoori AR (2015) Evaluation of cadmium resistant bacterium, Klebsiella Pneumoniae, isolated from industrial wastewater for its potential use to bioremediate environmental cadmium. Pakistan J Zool 47: 1533-1543

11. Yan G, Viraraghvan T (2003) Heavy-metal removal from aqueous solution by fungus Mucor rouxii. Water Res 37: 4486-4496

12. Pattanayak B, Mittra B, Dhal NK (2015) Cadmium bioremediation by metal - resistant mutated bacteria isolated from industrial effluent. Int J Pure App Biosci 3:296-303

13. Díaz-Raviña M, Bååth E (2001) Response of bacterial communities preexposed to different metals and reinoculated in an unpolluted soil. Soil Biology Biochemistry 33: 241-248

14. Díaz-Raviña M, Bååth $\mathrm{E}$, Frostegård (1994) Multiple heavy metal tolerance of soil bacterial communities and its measurement by a thymidine incorporation technique. Appl Environ Microbiol 60: 22382247

15. Villegas LB, Amoroso MJ, deFigueroa LIC (2005) Copper tolerant yeasts isolated from polluted area of Argentina. J Basic Microbiol 45 381-391

16. Zafar S, Aquil F, Ahmad I (2007) Metal tolerance and biosorption potential of filamentous fungi isolated from metal contaminated agricultural soil. Bioresource Technology 98: 2557-2561

17. Jiang C, Sheng X, Qian M, Wang Q (2008) isolation and characterization of a heavy metal-resistant Burkholderia sp. from heavy metalcontaminated paddy field soil and its potential in promoting plant growth and heavy metal accumulation in metal-polluted soil. Chemosphere 72 : 157-164

18. Rehman A, Farooq H, Hasnain S (2008) Biosorption of copper by yeast, Loddermyces elongisporus, isolated from industrial effluents: its potential use in wastewater treatment. J Basic Microbiol 48: 195-201

19. Cooley RN, Helen R, Tomsett AB (1986) isolation and characterization of cadmium-resistant mutants. Curr Microbiol 13: 265-268

20. Yamada T, Furukawa K, Hara S, Mizoguchi H (2005) Isolation of copper-tolerant mutants of sake yeast with defective peptide uptake. J Biosci Bioeng 100: 460-465

21. Díaz-Raviña M, Bååth E (1996) Development of metal tolerance in soil bacterial communities exposed to experimentally increased metal levels. Appl Environ Microbiol 62: 2970-2977

22. Gin YH, Clark AB, Slebos RJ, Al-Rafai H, Taylor JA, Kundel TA, Resnick MA, Gordenin A (2003) Cadmium is a mutagen that acts by inhibiting mismatch repair. Nat Gen 34: 326-329

23. Serero A, Lopes J, Nicolas A, Boiteux S (2008) Yeast genes involved in cadmium tolerance: Identification of DNA replication as a target of cadmium toxicity. DNA Repair 7: 1262-1275

24. Ruta L, Paraschivescu C, Matache M, Avramescu S, Farcassanu IC (2010) Removing heavy metals from synthetic effluents using "kamikaze" Saccharomyces cerevisiae cells. App Microbiol Biotechnol 85: 763-771

25. Lin X, Mou R, Cao Z, Xu P, Wu X, Zhu Z, Chen M (2016) Characterization of cadmium-resistant bacteria and their potential for reducing accumulation of cadmium in rice grains. Sci Total Environ 569-570: 97-104 